\title{
Implementation of lean manufacturing to reduce waste in production line with value stream mapping approach and Kaizen in division sanding upright piano, case study in: PT. X
}

\author{
W. A. Santosa* and M. Sugarindra \\ Industrial Department, Universitas Islam Indonesia, Jl. Kaliurang, Km 14.5, Yogyakarta, Indonesia
}

\begin{abstract}
PT. XY produces musical instruments such as Upright Pianos and Grand Pianos. Due to a competitive competition, a good quality product is highly required as well as increasing the production scale. To achieve these objectives, company needs to reduce wastes occurred in its production lines, particularly in the division of sanding panel upright piano (UP) which produces type of PE B1 pianos. High cycle time and lead-time are caused by wastes in UP panel sanding division. Therefore, it is needed improvements to be applied here so that the production lines will be run more effectively and efficiently. This study aims to identify wastes using Value Stream Mapping (VSM) as a tool of lean manufacturing and to implement the improvements using Kaizen. It is found that the wastes are motion and waiting. Furthermore, the improvements (kaizen) are focused on reducing motion and waiting wastes. It is shown that cycle time decreased from 51.16 minutes to 41.90 minutes, work in process or inventory can be reduced to 24 pcs over $32 \mathrm{pcs}$, and the lead-time is 0.167 days of 0.222 days.
\end{abstract}

\section{Introduction}

The increasing competition among manufacturing industries has pushed every company to leverage its productivity in various ways. PT. XY is a manufacturing company that produces the type of pianos as musical instruments. The company is growing with a wide range of improvement projects in order to increase productivity. A piano production process is broken down into several units including the division of Sanding Panel Upright Piano (UP). According to the observation, there are wastes occurred such as less effective process, the layout is not set properly, and the cycle time to produce a cabinet panel piano upright piano into one unit $\mathrm{X}$ models is longer than the normal time. X model has a cycle time by 51.16 minutes which is caused the daily target of this division not reached. Thus, lead-time becomes 0.222 days. In order to increase its production, PT. XY needs to create a shorter cycle time and lead time so that daily goals can be achieved as well as create a production line more effectively and efficiently.

A balancing between effective and efficient can be created by reducing waste [1]. Waste is all activities that have non-value added [2]. To eliminate waste, companies can use lean concepts. Lean is a continuous effort to eliminate waste and improve value-added products in order to deliver value to customers [3]. Tools that can used to reduce waste are Value Stream Mapping (VSM) and Kaizen. VSM can assist companies in identifying nonvalue-added activities [4] and Kaizen is continuous improvements to improve productivity [5].
This study aims to help company understands the real condition of production lines to identify existing waste, design the improvements needed, and determine the changes occurred after the improvement applied in the division of sanding panel UP. Improvements carried out with a focus on improvements that can reduce cycle time and lead time in accordance with the company expected.

\section{Literature Review}

\subsection{Lean Manufacturing}

Lean manufacturing can be defined as a systemic approach and systematic to identify and eliminate waste or activities that are not value-added through the continuous improvement radically by flowing the product (material, work in process, output) and information using pull system of internal and external customers for the pursuit of excellence and perfection in the manufacturing industry [6].

\subsection{Waste}

Waste is anything other than the minimum amount of equipment, materials, parts, and labor (working time) which are essential to add value to the product [7]. There are seven kinds of waste defined according to [8]:

\section{- Overproduction}

The waste of overproduction is considered as the most serious waste as it discourages a smooth flow of goods

\footnotetext{
* Corresponding author: wijiagungsantosa@icloud.com
} 
or services and is likely to inhibit quality and productivity. Overproduction also tends to lead excessive lead and storage times.

- Defect

The waste of defects are errors occured when working processes, product quality and bad delivery performance.

- Unnecessary Inventory

The waste of unnecessary inventory is excess storage of goods, as well as the delay of a product or material information that lead to increased costs and decreased quality of service to the customer.

- Inappropriate processing

The waste of inappropriate processing is production process which is not appropriate for any of the procedures, the use of equipment or machinery that is not in accordance with the capacity and ability to work.

- Excessive transportation

The waste of excessive transportation includes any movement of people, information, product or material.

- Waiting

The waste of waiting occurs when time is not being used effectively, worker inactivity, information, material or product, each spending time waiting in a long period.

- Motion Unnecessary

The waste of motion unnecessary is whenever use of time does not add any value to the product nor process.

\subsection{Value Stream Mapping}

Value Stream Mapping (VSM) is a tool that is ideal as a first step in the process of change to get condition lean manufacturing or lean enterprises [9]. VSM is a tool to identify activities that value added and non-value added in the manufacturing industry, making it easier to find the root problems in the process $[10,11]$. State that the VSM is a method of lean process flow that can be reached by a three-stage method [12]. 1). Describe a current state map. 2). Identify the root causes of the problems that hinder the process of improvement, repair process determines what can done in the process flow, and then described it in a future state map. 3). Determine the implementation plan improvements to the production process of the company. Making the VSM uses certain symbols to describe the process of waiting, storage, decision-making, queues and inspection [13].

\subsection{Kaizen}

Kaizen is a term in the Japanese language that can interpreted as continuous improvement [6]. Kaizen means continuous improvement involving everyone, both the top management, managers and employees and principal strategy kaizen is to realize that the management should strive to satisfy customers and meet customer needs [14].

\section{Method}

Data collected are standard time, Standard Process Flow, and Work in Process by using video recorder and a stopwatch. Then, the current state mapping is drawn to understand a clear picture related to the processing time. After the wastes have been identified, some improvements are designed to fix these problems using Kaizen. The Kaizen approved will implemented, as a further corrective action will be carried out a new mapping to the condition after the repair in order to know what changes occur.

\section{Result and Discussion}

The data used has been tested the adequacy and the uniformity of the data with the overall results of data fairly and uniformly. Then, collect the data of WIP or inventory that will be included in the mapping of the Current State Value Stream Mapping. The process flow map Current State Value Stream Mapping illustrated as follows:

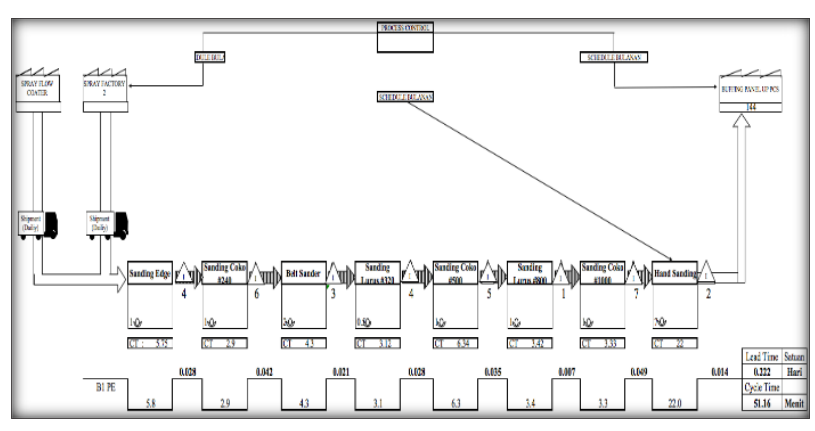

Fig 1. Current state mapping section sanding model A

Current state mapping is drawn from the previous process, which is part of Painting and will be sent to the buffing UP Panel. Before sending the material to buffing, material goes through the process of sanding edge (\#240 - \#1000) until hand sanding process.

The process of hand sanding is the longest cycle time of 22 minutes. It is because of a manual process without machines utilization, just ategi and abrasives involved to the process. For the longest cycle time process where the machine involved is sanding machine surfaces sanding \#500 by 6:34 minutes. The machine sanding \#500 is an automatic machine so that the processing time will depend on the machine setting. While, the fastest cycle time is 2.90 minutes which belongs to the process of sanding surface machine sanding\# 320. Then, the total cycle time on production lines Sanding UP Panel is 51.16 minutes. Besides the cycle time, it is found that the sanding surface machine sanding $\# 240$, the process of sanding surface machine sanding $\# 500$, and the sanding surface machine sanding \#1000 have bottleneck. This is caused by the unbalanced cycle time and the total lead-time occured in UP Panel Sanding is 0.222 days. The waste identified and proposals kaizen will be explained clearly in Table 1 . 
Table 1. Identification of waste and proposals Kaizen.

\begin{tabular}{|c|c|c|c|}
\hline No & Problem Finding & Propose Kaizen & $\begin{array}{l}\text { Waste } \\
\text { Category }\end{array}$ \\
\hline 1 & $\begin{array}{l}\text { Process sanding surface machine sanding } \# 240 \\
\text { and machine } \# 500 \text { sanding capacity of setting } \\
\text { only } 2 \text { pcs per process }\end{array}$ & $\begin{array}{l}\text { Promvide Stopper in order to increase setting process } \\
\text { sanding surface machine sanding\# } 240 \text { capacity and Top } \\
\text { Board, machine sanding\# } 500 \text { to be } 3 \text { pcs per process for } \\
\text { cabinet Fall Center. }\end{array}$ & Motion \\
\hline 2 & $\begin{array}{l}\text { Process sanding surface sanding machine } \\
\# 1000 \text { capacity setting only } 1 \text { pcs per process }\end{array}$ & $\begin{array}{l}\text { Provide Stopper so that setting the process sanding surface } \\
\text { sanding machine } \# 1000 \text { capacity can be } 2 \text { pcs per process for } \\
\text { cabinet Fall Center. }\end{array}$ & Motion \\
\hline 3 & $\begin{array}{l}\text { Adjusment button Foot Pad cylinder on the } \\
\text { sanding machine } \# 1000 \text { too Far. }\end{array}$ & $\begin{array}{l}\text { Changing the position or add a key regulator of the cylinder } \\
\text { pad foot next to the operator. }\end{array}$ & Motion \\
\hline 4 & $\begin{array}{l}\text { Process mentored sanding is still using a hand } \\
\text { sanding (ategi) so it takes a longer time. }\end{array}$ & $\begin{array}{l}\text { The use orbital sanding to simplify and make the process } \\
\text { mentored sanding faster. }\end{array}$ & Motion \\
\hline 5 & $\begin{array}{l}\text { Sanding machine } \# 500 \text { often does not work } \\
\text { because solenoid often broke }\end{array}$ & $\begin{array}{l}\text { Repair sanding machine } \# 500 \text { so that it will more stable and } \\
\text { work properly }\end{array}$ & Waiting \\
\hline 6 & $\begin{array}{l}\text { Motor meja sanding } \# 500 \text { sering terbakar, } \\
\text { sehingga level naik turunnya meja tidak dapat } \\
\text { dilakukan. }\end{array}$ & $\begin{array}{l}\text { Perbaikan mesin sanding \#500 agar kondisinya stabil dan } \\
\text { berfungsi dengan baik }\end{array}$ & Waiting \\
\hline 7 & $\begin{array}{l}\text { Karena mesin } \# 500 \text { adalah mesin automatic } \\
\text { membuat proses Sanding mesin } \# 500 \text { lama } \\
\text { karena kecepatan maju mundur meja mesin } \\
\text { yang lama }\end{array}$ & Mempercepat kecepatan maju mundur meja mesin $\# 500$ & Waiting \\
\hline
\end{tabular}

After Kaizen applied, a Future State Value Stream Mapping is built. The process drawn in Future State Value Stream Mapping is similar with the existing process in the Current State Value Stream Mapping. This is because there is no kaizen eliminating processes in sanding UP Panel. The Future State Value Stream Mapping is illustrated in Fig 2.

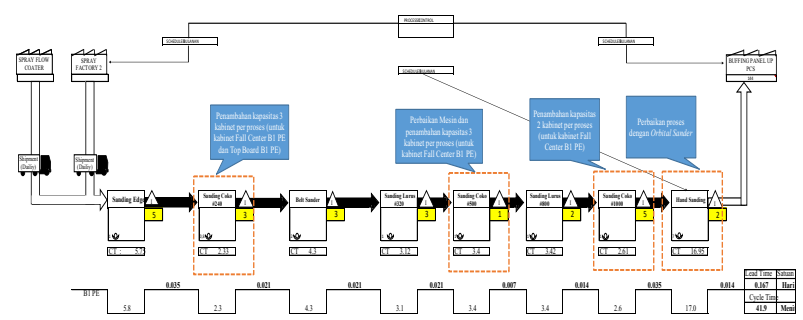

Fig 2. Future state value stream mapping section sanding model A.

\section{Conclusion and Recommendation}

\subsection{Conclusion}

Based on current state mapping, the hand sanding has the longest cycle time by 22 minutes. The longest cycle time of machine process is sanding machine surfaces sanding \#500 up to 6:34 minutes. Meanwhile, the fastest cycle time is process sanding surface machine sanding \#320 reaching 2.90 minutes. Thus, the total cycle time on production lines Sanding UP Panel is 51.16 minutes. There are a few processes having bottleneck: the process of sanding surface machine sanding \#240, the process of sanding surface sanding machine \#500, and the sanding surface sanding machine \#1000.
The implementation of Kaizen has given a couple of changes in decreasing cycle time: (1) sanding machine \#240 has become 0.57 minutes from 2.90 minutes; (2) machine sanding \#500 is 3.40 minutes compared to 6.34 minutes; (3) machine sanding \#1000 is eliminated more than 0.70 minutes or it is 2.61 minutes now; and (4) process of hand sanding is exactly 17 minutes, 5 minutes faster. Thus, the total of cycle time of division sanding panel up has been reduced for almost 9.3 minutes from the previous total of 51.16 minutes. Inventory reaches 24 pcs or it decreases 6 pcs. Finally, the previous 0.222-day lead time has been increased to 0.167 days.

\subsection{Recommendation}

According to these results, PT. XY should keep maintaining the continous improvements into the production line so it will always be lean and any wastes occured can be reduced. For further, an improvement or kaizen may be design for processes using machines of straight sanding such as sanding process of the surface sanding machine \#320 and sanding process of the surface sanding machine \#800. It is also interesting to conduct a simulations in order to know whether there is any impact if the sanding machine $\# 500$ is changed from the automatic into manual machine.

\section{References}

1. D. M. Utama, S. K. Dewi, V. I. Mawarti, Identifikasi Waste Pada Proses Produksi Key Set Clarinet Dengan Pendekatan Lean Manufacturing, 15, 1 (2016).

2. A. Maulana, L. Herlina, B. Kurniawan, Usulan Lean Manufacturing System untuk Mereduksi Waste Dan 
Efisiensi Biaya Produksi Di PT. ABC Divisi Slab Steel Plant 1. 4, 3 (2016).

3. V. Gaspersz, A. Fontana, Lean Six Sigma for Manufacturing and Service Industries, (2011).

4. T. Prayogo, T. Octavia, Identifikasi Waste dengan Menggunakan Value Stream Mapping di Gudang PT. XYZ, 1, 2 (2013).

5. E. A. P. H. Putra, Z. F. Ikatrinasari, Penerapan Lean Manufacturing Melalui Metode Gemba Kaizen Dengan Pendekatan Siklus Pdca Untuk Peningkatan Produktivitas Di PT. XYZ, BEKASI, 3, 2 (2012).

6. V. Gaspersz, Lean Six Sigma for manufacturing and service industries, (2007).

7. T. Narusawa, J. Shook, Kaizen Express 2nd edition, (2008).

8. P. Hines, D. Taylor, Going Lean, (2000).
9. Goriwondo, M. William, M. Samson, M. Alphonce, Use of The Value Stream Mapping Tool for Waste Reduction in Manufacturing (Case Study for Bread Manufacturing in Zimbabwe), (2011).

10. Mc. Williams, L. Douglas, E. G. Tetteh, Value-Stream Mapping to Improve Productivity in Transmission Case Machining, (2008).

11. M. Tilak, E. Van Aken, T. McDonald, K. Ravi, Value Stream Mapping: A Review and Comparative Analysis of Recent Applications, (2002).

12. A. Rahani, M. al-Ashraf, Production flow analysis through value stream mapping: a lean manufacturing process study, (2012).

13. B. El-Haik, R. Al-Omar, Simulation Based Lean Six Sigma and Design For Six Sigma, (2006).

14. M. Imai, Kaizen Kunci Sukses Jepang Dalam Persaingan, (2001). 